\title{
Złoża gazu ziemnego we wschodniej części Morza Śródziemnego: implikacje dla Cypru
}

\section{Wprowadzenie}

Odkrycie wielkich złóż gazu ziemnego we wschodniej części Morza Śródziemnego stanowi szansę nie tylko na powszechne wzbogacenie, wzrost wolumenu inwestycji czy zwiększenie liczby miejsc pracy, ale może przyczynić się także do wzrostu regionalnego bezpieczeństwa i stanowić zachętę do uregulowania dotychczasowych sporów. Jest też druga strona medalu. Kwestia eksploatacji złóż może wywoływać nowe spory lub nawet doprowadzić do konfliktu. W przypadku złóż cypryjskich oba scenariusze są nadal prawdopodobne. Nieuregulowany problem polityczny wpływa bowiem pośrednio na kwestie energetyczne, zwłaszcza możliwości inwestycyjne związane z późniejszym przesyłem. Kluczową rolę odgrywają trzy strony: 1) Republika Cypryjska, która de facto jest państwem podzielonym i administrowanym jedynie przez Greckich Cypryjczyków; 2) nieuznawana przez społeczność międzynarodową, za wyjątkiem Turcji, Turecka Republika Północnego Cypru - państwo Tureckich Cypryjczyków oraz 3) Turcja. Celem niniejszego rozdziału jest zbadanie wpływu kwestii energetycznych na pozycję Cypru w regionie, jego sytuację gospodarczą oraz negocjacje pomiędzy Greckimi i Tureckimi Cypryjczykami.

Kwestia cypryjska od prawie czterdziestu lat pozostaje jednym z najdłużej nieuregulowanych sporów międzynarodowych. Tureckich Cypryjczyków i Greckich Cypryjczyków dzieli prawie wszystko. Między stronami nie ma zgody nawet co do tego, jaki moment należy uznać za początek sporu. Tureccy Cypryjczycy wskazują na walki między członkami obu społeczności w latach 1963-1964 i będący ich konsekwencją faktyczny koniec demokracji konsocjacyjnej, obowiązującej w Republice Cypryjskiej na podstawie Konstytucji z 1960 roku. Z kolei Greccy Cypryjczycy uważają, iż momentem przełomowym było naruszenie integralności terytorialnej Cypru przez Turcję latem 1974 roku ${ }^{1}$. Jedną z jego konsekwencji pozostaje faktyczny podział wyspy, który nabrał szczególnego znaczenia po jednostronnej deklaracji utworzenia własnego państwa przez społeczność Tureckich Cypryjczyków w północnej części wyspy z 15 listopada 1983 roku. Wówczas proklamowana została Turecka Republika Północnego Cypru, którą de iure uznała jedynie Turcja.

1 Więcej na temat źródeł, przebiegu i konsekwencji kwestii cypryjskiej zob. A. Adamczyk, Cypr - dzieje polityczne, Wydawnictwo Akademickie Dialog, Warszawa 2002; P. Osiewicz, Pokojowa regulacja kwestii cypryjskiej. Aspekty prawne i polityczne, Wydawnictwo Mado, Torun 2008; P. Osiewicz, Konflikt cypryjski, Wydawnictwo Naukowe PWN, Warszawa 2013. 
W tak złożonym kontekście politycznym nie może stanowić zaskoczenia fakt, iż wszystkie dotychczasowe próby uregulowania sporu zakończyły się niepowodzeniem. Wielki wysiłek włożony w proces zbliżenia stron przez kolejnych sekretarzy generalnych ONZ w ramach misji dobrych usług w praktyce nie tylko nie zaowocował osiagnięciem porozumienia, ale nawet nie doprowadził do jakiegokolwiek przełomu w negocjacjach, nie licząc dwustronnych porozumień z 1977 i 1979 roku, które do dzisiaj wyznaczają ramy dla procesu negocjacyjnego. Skoro obu społeczności nie można połączyć dzięki procesowi dialogu politycznego, może mogłoby się to stać dzięki pojawieniu się wspólnego interesu, zwłaszcza bardzo wymiernego, który przyniósłby określone zyski zarówno Greckim Cypryjczykom, jak i Tureckim Cypryjczykom?

Szansa na rozwój takiego scenariusza pojawiła się wraz z odkryciem bogatych zasobów gazu ziemnego pod szelfem we wschodniej części Morza Śródziemnego. Udokumentowane złoża zlokalizowane są przede wszystkim w okolicach południowych wybrzeży Cypru, znajdujących się pod efektywną kontrolą władz Republiki Cypryjskiej. Równocześnie pojawiły się sygnały, iż inne złoża mogą znajdować się w strefie wód de facto kontrolowanych przez Turecką Republikę Północnego Cypru.

Niniejszy artykuł stanowi próbę ustalenia wpływu kwestii surowcowej na proces negocjacyjny na Cyprze oraz jego relacje z Turcją. Czy odkryte złoża gazu stanowią szansę na zbliżenie stanowisk, czy też wręcz przeciwnie - są kolejnym potencjalnym polem konfliktu? Skoro w ramach procesu integracji europejskiej wspólnota interesów gospodarczych pomogła przezwyciężyć podziały polityczne oraz powojenne urazy, czy taki sam scenariusz może zaistnieć również na Cyprze? By to ustalić, analizie poddane zostały dostępne dokumenty dotyczące wielkości złóż oraz planów ich eksploatacji, oświadczenia polityków po obu stronach linii Attyli oraz działania podejmowane zarówno przez kierownictwa obu cypryjskich społeczności, jak również przez rozmaite podmioty gospodarcze działające na ich zlecenie.

\section{Złoża gazu ziemnego we wschodniej części Morza Śródziemnego: implikacje regionalne}

W 2004 roku Tassos Papadopulos, ówczesny Prezydent Republiki Cypryjskiej, ogłosił, iż Cypr skorzysta z prawa do ustanowienia wyłącznej strefy ekonomicznej (EEZ - Exclusive Economic Zone), przysługującego mu na mocy Konwencji Narodów Zjednoczonych o prawie morza z 1982 roku (Kariotos, 2011, s. 45-56). Artykuł 56 Konwencji stanowi, jakie prawa przysługują państwu w ramach jego EEZ. Zaliczają się do nich:

- prawo do „badania, eksploatacji i ochrony zasobów naturalnych, zarówno żywych, jak i nieożywionych, wód morskich pokrywających dno, a także dna morskiego i jego podziemia oraz gospodarowania tymi zasobami”;

- prawo budowania i wykorzystywania sztucznych wysp, instalacji i konstrukcji;

- prawo do prowadzenia badań naukowych morza;

- prawo do ochrony i zachowania środowiska morskiego (Konwencja, 1982).

Co niezwykle istotne, każde państwo korzystające we własnej EEZ z przysługujących mu praw, musi jednocześnie uwzględniać prawa i obowiązki innych państw. 
W złożonej sytuacji dotyczącej cypryjskiej EEZ, sprawę dodatkowo komplikuje istnienie dwóch suwerennych brytyjskich baz wojskowych na Cyprze - Dekelii i Akrotiri. $Z$ prawnego punktu widzenia nawet brytyjskie władze mogłyby się domagać udziału w podziale cypryjskiego szelfu, a także udziału w zyskach, pochodzących z jego potencjalnej eksploatacji. Na podstawie umowy z 1960 roku władze Republiki Cypryjskiej zrzekły się wszelkich roszczeń nie tylko w stosunku do samych baz, ale także przyległych do nich obszarów morskich (The 1960 Treaties, s. 23).

W świetle powyższych uregulowań, nie może dziwić fakt, że pierwsze potwierdzone odwierty na szelfie we wschodniej części Morza Śródziemnego - izraelskie pola Noa (1999) i Mari-B (2000) - zachęciły władze Republiki Cypryjskiej do ustanowienia własnej EEZ oraz zainicjowania poszukiwań złóż. Decyzja zbiegła się w czasie z rozpoczęciem eksploatacji złóż Mari-B przez Izrael.

Obecnie w tak zwanym basenie Lewantu występuje kilkanaście potwierdzonych złóż. Prawie wszystkie, za wyjątkiem cypryjskiego pola Afrodyta, są położone w EEZ Izraela. Są to, między innymi, największe spośród dotychczas odkrytych złóż - Tamar, 2009 oraz Lewiatan, 2010 (Eastern, 2013). Geolodzy zakładają, że złóż jest o wiele więcej, także w strefach innych państw, niemniej nie są to jeszcze informacje potwierdzone przez udane odwierty.

Intencją Republiki Cypryjskiej jest wykorzystanie odkrycia złóż gazu we wschodniej części Morza Śródziemnego do wzmocnienia swej pozycji regionalnej, a także rozwoju integracji z państwami regionu. W lipcu 2013 Prezydent Republiki Cypryjskiej Nikos Anastasiadis oświadczył: „Cypr może stać się filarem współpracy energetycznej państw położonych we wschodniej części Morza Śródziemnego. Mój rząd jest zdeterminowany i zdecydowany, by wybudować terminal do skraplania i późniejszego eksportu gazu LNG. Budowa sieci przesyłowej gazu ziemnego we wschodniej części Morza Śródziemnego umocni regionalne bezpieczeństwo energetyczne, przyciagnie inwestycje zagraniczne, przyczyni się do utworzenia nowych miejsc pracy, a przede wszystkim stanie się źródłem wzrostu gospodarczego dla wszystkich państw regionu. Energia nie powinna być źródłem konfliktu, lecz narzędziem służącym do rozwiązywania konfliktów oraz pogłębiania regionalnej integracji” (Interview, 2013, s. 13).

Idealistyczne plany i najlepsze założenia nie mogą jednak, niestety, wyeliminować równoległych zagrożeń. Owszem, złoża mogą stanowić zachętę do rozwijania regionalnej współpracy, ale mogą stać się również przedmiotem nowych sporów międzynarodowych. Zdaniem Jamesa Stockera współpraca energetyczna w regionie wschodniego Morza Śródziemnego nie będzie możliwa z wielu powodów. Na przeszkodzie staną przede wszystkim nieuregulowane kwestie polityczne takie jak brak stosunków dyplomatycznych pomiędzy Izraelem a Libanem, napięte ostatnio relacje Izraela z Egiptem, rywalizacja grecko-turecka czy też wreszcie, najbardziej interesujący w kontekście niniejszego artykułu, brak stosunków dyplomatycznych i rywalizacja pomiędzy Republiką Cypryjską a Turcją (Stocker, 2012, s. 579-580). Przykładowo, Liban i Izrael prowadzą spór dotyczący przebiegu granic ich wyłącznych stref ekonomicznych.

Turcja oraz Tureccy Cypryjczycy postanowili oprotestowywać zawieranie przez Cypr umów z innymi państwami w regionie odnośnie przebiegu granic wyłącznych 
stref ekonomicznych ${ }^{2}$. Tak stało się, na przykład, w przypadku umowy cypryjsko-libańskiej z 2007 roku. By blokować działania rządu Republiki Cypryjskiej, Turcja oraz władze Tureckiej Republiki Północnego Cypru także podpisały umowę rozdzielającą szelf między nimi, co spotkało się ze zdecydowaną reakcją Greckich Cypryjczyków. Po pierwsze dlatego, iż władze Republiki Cypryjskiej nie uznają państwa Tureckich Cypryjczyków i uznają północny Cypr za obszary okupowane. Tym samym odmawiają Tureckim Cypryjczykom prawa do zawierania jakichkolwiek umów. Po drugie, podział szelfu miał być niekorzystny z cypryjskiego punktu widzenia, gdyż Turcja otrzymała znaczące obszary znajdujące się de facto w cypryjskiej wyłącznej strefie ekonomicznej.

Co ciekawe, już w 2003 roku Cypr podpisał z Egiptem umowę o ustaleniu przebiegu granicy pomiędzy ich wyłącznymi strefami ekonomicznymi i to w sytuacji, gdy sam jeszcze nie zadeklarował utworzenia takiej strefy. Zmiana nastąpiła w 2004 roku, gdy przyjęta została ustawa nr 64, na mocy której Cypr ustanowił własną EEZ (Kariotos, 2011, s. 47). Jak dotychczas, dwustronnym dokumentem o największym znaczeniu politycznym pozostaje umowa pomiędzy Izraelem a Republiką Cypryjska, zawarta 17 grudnia 2010 roku. Na jej podstawie oba państwa uzgodniły przebieg granicy na styku wyłącznych stref ekonomicznych. I w tym przypadku nie obyło się bez tureckiego sprzeciwu. Władze Turcji wysłały kilka not protestacyjnych do Sekretarza Generalnego ONZ (Stocker, 2012, s. 585-586). Takie działania nie są w stanie zablokować cypryjskich poszukiwań, lecz z pewnością przyczyniają się do wzrostu niepewności wśród potencjalnych inwestorów.

\section{Rozdział koncesji na poszukiwania i eksploatację złóż cypryjskich, czyli wielkie mocarstwa wracają do gry}

Amerykańska firma Noble Energy International, zajmująca się poszukiwaniami i wydobyciem gazu z izraelskich złóż we wschodniej części Morza Śródziemnego (Tamar, Lewiatan), wygrała przetarg na prowadzenie pierwszego etapu poszukiwań w wyłącznej strefie ekonomicznej Cypru. Za przełomowy moment uznaje się grudzień 2011 roku, gdy sukcesem zakończył się odwiert w strefie 12, znajdującej się na polu gazowym Afrodyta. Analitycy Noble Energy ocenili wielkość złóż na 198 miliardów m³ które mogłyby pokryć zapotrzebowanie na gaz na Cyprze w okresie około 100 lat i jeszcze pozwoliłyby na jego eksport (Country Review, 2012, s. 39).

Wkrótce po odkryciu bogatych złóż strefy 12, ówczesny Prezydent Dimitris Christofias zadeklarował: „W przypadku eksploatacji złóż gazu, staramy się postępować rozsądnie w ramach granic wyłącznej strefy ekonomicznej Republiki Cypryjskiej.

2 Warto zaznaczyć, że Turcja nie jest stroną Konwencji NZ o prawie morza. Główną przyczyną takiego stanu rzeczy stanowią spory z Grecją w basenie Morza Egejskiego. Więcej na ten temat zob. P. Osiewicz, Spory grecko-tureckie w basenie Morza Egejskiego, w: Spory-konflikty zbrojne-terroryzm. Dysfunkcjonalne czynniki współczesnych stosunków międzynarodowych, pod red. W. Malendowskiego, Wydawnictwo Naukowe WNPiD UAM, Poznań 2006. Zob. także: M. X. Kyriakou, Kryzys egejski, MAW, Warszawa 1989. 
Będziemy nadal poszukiwali kolejnych złóż w granicach prawa międzynarodowego, a zwłaszcza prawa morza" (Interview with Demetris Christofias, 2012, s. 20).

Tak dobre informacje wprowadziły w stan euforii nie tylko inwestorów, ale także cypryjskich polityków. Pojawiły się odważne projekty inwestycji w przemysł energetyczny. Zaplanowano, między innymi, budowę gazociągu łączącego terminal w Vassilikos z polem gazowym Afrodyta oraz budowę terminala LNG. Wartość samych inwestycji w Vassilikos wyceniono na około 300 milionów euro, natomiast budowę terminala LNG na aż 10 miliardów USD. I tym razem sukces odniosła strona amerykańska (Noble Energy), która, jak dotychczas, skutecznie eliminuje z gry koncerny rosyjskie, żywotnie zainteresowane cypryjskimi złożami ze względu na bardzo dobre relacje polityczne i gospodarcze z Cyprem (Interview with Demetris Christofias, 2012, s. 20). Memorandum w sprawie terminala LNG zostało podpisane w czerwcu 2013 roku. Na jego podstawie wiadomo, że inwestycja ma zostać zrealizowana dzięki współpracy trzech podmiotów (amerykańskiego Noble Energy oraz izraelskich Delek Drilling i Avner Oil Exploration). Jej skala wpływa jednak na termin realizacji - 15 lat. Budowa ma się rozpocząć w 2015 roku.

Cypryjczycy nadal zakładają, że ich terminal LNG mógłby obsłużyć także złoża izraelskie, ale obecnie wiele wskazuje na to, iż Izrael planuje własną inwestycję tego typu (Eastern, 2013). Decydują o tym zapewne względy bezpieczeństwa, a nie tylko rachunek ekonomiczny. W ten sposób Izrael uniezależni się zarówno pod względem dostępu do gazu, jak i jego eksportu.

Alternatywę dla budowy instalacji LNG stanowi rozbudowa regionalnej sieci przesyłowej (gazociagi). W grę wchodzą trzy inwestycje: 1) budowa rurociągu ze wschodniej części Morza Śródziemnego do Krety, 2) nowy gazociąg łączący złoża z Turcją oraz 3) budowa gazociagu do Egiptu i wykorzystanie jego infrastruktury LNG (Eastern, 2013). Powyższy plan jest jednak mniej atrakcyjny z co najmniej dwóch powodów. Po pierwsze, jest to wysoki koszt budowy podmorskich odcinków rurociąów. Po drugie, nieuregulowane kwestie prawne i polityczne w regionie. W tym kontekście należy zwrócić uwagę na napięte stosunki Turcji z Cyprem i Izraelem, wojnę domową w Syrii, brak stosunków dyplomatycznych pomiędzy Izraelem i Libanem, a także niestabilność polityczną w Egipcie. Niemniej, bez względu na sposób transportu, Cypr planuje sprzedaż gazu na dużą skalę na rynkach europejskich. Charles Ellinas, Prezes Cyprus National Hydrocarbons Company (CNHC), poszedł nawet o krok dalej i zadeklarował, że Cypr jest w stanie pokryć do 30\% wzrostu zapotrzebowania na gaz ziemny w Europie, prognozowanego do roku 2025 (Cyprus, 2013, s. 7). W tym kontekście warto jednak zwrócić uwagę na ustalenia ekspertów International Crisis Group, w których raporcie z 2 kwietnia 2012 r. znalazły się o wiele mniej optymistyczne prognozy. Pojawiło się nawet stwierdzenie, że omawiane zasoby są zbyt małe, by mogły w znaczący sposób wpłynąć na dywersyfikację źródeł zaopatrzenia Europy w gaz ziemny. Ponadto, ICG zarzuciło Unii Europejskiej brak prowadzenia jakiejkolwiek proaktywnej polityki dotyczącej eksploatacji złóż w regionie wschodniego Morza Śródziemnego (Aprodite’s Gift, 2012, s. 8).

Na przeszkodzie cypryjskich poszukiwań stoi stanowisko Turcji, która broni interesów własnych oraz interesów Tureckich Cypryjczyków. Na przykład, w listopadzie 2012 turecki minister energii Taner Yıldız miał przestrzec włoski koncern ENI, że jeśli 
ten przyjmie zlecenie poszukiwania gazu od cypryjskich władz (sektory 2 i 3), wówczas turecki rząd przeprowadzi rewizję inwestycji ENI w Turcji (Gürel, Mullen, Tzimitras, 2013, s. 73). Wspominane sektory znajdują się w strefie, do której roszczenia wysuwają Tureccy Cypryjczycy. Włoski koncern miał prowadzić poszukiwania wspólnie z południowokoreańską firmą KOGAS.

\section{Złoża gazu i ich wpływ na kwestię cypryjską: nowe pole konfliktu?}

W rozwiązywaniu wszelkich sporów lub nawet konfliktów międzynarodowych dużą rolę odgrywa świadomość istnienia wspólnego interesu lub interesów. Wizja potencjalnych korzyści doskonale wpisuje się w model racjonalnego wyboru, zgodnie z którym decydenci dążą do maksymalizacji zysków, a jednocześnie starają się zminimalizować ryzyko strat lub straty. Warto przypomnieć, że w przeszłości świadomość istnienia wspólnego interesu została umiejętnie wykorzystana przez inicjatorów procesu integracji europejskiej, przede wszystkim zaś umożliwiła zbliżenie francusko-niemieckie. Bez ówczesnego porozumienia na linii Paryż-Bonn, budowa zjednoczonej Europy byłaby niemożliwa. W momencie, gdy tworzono Europejską Wspólnotę Węgla i Stali, minęło zaledwie sześć lat od zakończenia II wojny światowej. Pamięć okropieństw wojny i wzajemna niechęć były jeszcze bardzo silne, a jednak niemożliwe stało się możliwe - dwa wrogie państwa zaczęły współpracować. Czy zatem w o wiele mniej złożonej sytuacji, jaką jest spór cypryjski, nie ma szansy na pojednanie dzięki uświadomieniu Tureckim i Greckim Cypryjczykom istnienia wspólnego interesu?

Już pierwsze sygnały o możliwości występowania zasobnych złóż gazu ziemnego pod szelfem należącym do Republiki Cypryjskiej rozpaliły wyobraźnię badaczy i analityków kwestii cypryjskiej. Skoro bowiem, zgodnie z oficjalnym stanowiskiem cypryjskich władz, wyspę zamieszkują dwie równoprawne społeczności, to będą musiały osiagnąć kompromis w sprawie podziału ewentualnych zysków z eksploatacji złóż. Ale jednocześnie władze Republiki Cypryjskiej stawiają jeden, bardzo istotny warunek - uregulowanie sporu i przekształcenie Cypru w państwo federalne. Tureccy Cypryjczycy nie będą mieli możliwości skorzystać z podziału zysków ze sprzedaży gazu, jeśli zachowane zostanie status quo. Tym samym kwestia wydobycia gazu może stanowić impuls dla rozważań nad możliwością intensyfikacji negocjacji oraz nad możliwościami i formą ewentualnego porozumienia. Przedstawiciele Greckich Cypryjczyków próbują wykorzystać kwestie energetyczne do skłonienia strony tureckiej do uelastycznienia jej stanowiska. Świadczą o tym wypowiedzi niektórych wpływowych polityków. Przykładowo, Prezydent Dimitris Christofias oświadczył w 2011 roku: „Mogę zapewnić Tureckich Cypryjczyków, że nie mają niczego do stracenia. Wręcz przeciwnie, mogą wiele zyskać, gdy kwestiami związanymi z eksploatacją złóż węglowodorów zajmować się będzie rząd cypryjskiej federacji. Wówczas rząd federalny rozdzieli wszelkie zyski pomiędzy dwie części składowe" (Gürel, Mullen, Tzimitras, 2013, s. 43).

Swoje roszczenia zgłaszają jednak Tureccy Cypryjczycy, którzy domagają się udziału w ewentualnych zyskach, ale nie na zasadzie faktów dokonanych w rodzaju najpierw rozwiązanie kwestii cypryjskiej, potem udział w zyskach. Władze TRPC 
podważają też prawo Greckich Cypryjczyków do delimitacji EEZ z 2004 roku bez jakichkolwiek konsultacji ze stroną Tureckich Cypryjczyków. Na tej podstawie oprotestowały podpisane przez Republikę Cypryjską z innymi państwami umowy dotyczące delimitacji EEZ. W 2007 roku, po podpisaniu umowy cypryjsko-libańskiej, ówczesny Prezydent TRPC Mahmet Ali Talat powiedział: „Umowa podpisana przez administrację Greckich Cypryjczyków jako rząd Republiki Cypryjskiej jest nieważna i niebyła, i w żadnym stopniu nie dotyczy Tureckich Cypryjczyków czy wyspy jako całości" (Gürel, Mullen, Tzimitras, 2013, s. 47). W tym zakresie mogą liczyć na wsparcie ze strony Turcji, która, poza obroną interesów TRPC, ma na uwadze również własne interesy i plany w sektorze energetycznym. Plany budowy cypryjskiego terminala w Vassilikos zagrażają innej, wielkiej inwestycji w regionie - tureckiemu terminalowi surowcowemu Ceyhan. Ponadto, Turcja wspiera Tureckich Cypryjczyków w procesie odwiertów i poszukiwań złóż gazu w północnej części wyłącznej strefy ekonomicznej Cypru, co z kolei spotyka się ze zdecydowanym sprzeciwem ze strony władz Republiki Cypryjskiej.

Strona Tureckich Cypryjczyków rozpoczęła własne odwierty w kwietniu 2012 roku. Ponieważ TRPC nie dysponuje własnym kapitałem, ani sprzętem, podobnie jak Greccy Cypryjczycy korzysta z usług wyspecjalizowanej firmy. Wybrano, co nie mogło stanowić żadnego zaskoczenia, koncern turecki - Turkish Petroleum Corporation (TPAO). Wybór poprzedziły osobiste uzgodnienia pomiędzy premierem Turcji Recepem Tayyipem Erdoğanem i prezydentem TRPC Dervişem Eroğlu z września 2011 roku. W rozpoczęciu pierwszego, symbolicznego odwiertu na polu Turkyurdu-1 uczestniczył turecki minister energii Taner Yıldız, który oświadczył: „Kwestie energetyczne przyczyniają się do wybuchu wojen na świecie, ale w przypadku tej wyspy doprowadzą do pokoju" (Turkey launches, 2013). Przy okazji poinformował także, że Turcja otrzymała przedtem, pośrednio, kilka propozycji współpracy przy odwiertach ze strony Greckich Cypryjczyków, ale, co znamienne, od razu dodał: „Nie rozważamy prowadzenia prac technicznych niezależnie od rozwoju sytuacji politycznej" (Turkey launches, 2013). Również Derviş Eroğlu nie ukrywał, że prowadzone prace mają nie tylko wymiar ekonomiczny, ale także polityczny. W odniesieniu do zacieśniania relacji pomiędzy północnym Cyprem i Turcją powiedział: „Jesteśmy świadkami historycznej chwili. Kolejne ogniwo, ważne ze względów strategicznych, zostało dodane do łańcucha braterstwa, jedności serc i współpracy" (Turkey launches, 2013).

Jak już wcześniej wspomniano, rozpoczęcie odwiertów w rejonie Turkyourdu-1 spotkało się ze zdecydowanym sprzeciwem Republiki Cypryjskiej. Greccy Cypryjczycy nie byli oczywiście w stanie zablokować prac, ale rzecznik rządu Stafanos Stefanu wyraźnie podkreślił, że Republika Cypryjska uznaje działania tego typu za przejawy złej woli i pogwałcenia prawa, zwłaszcza że Tureccy Cypryjczycy powierzyli prowadzenie odwiertów w cypryjskiej wyłącznej strefie ekonomicznej firmie tureckiej (Turkey approves, 2013). Republika Cypryjska niezmiennie podkreśla, że północny Cypr oraz przyległy do niego szelf znajdują się pod turecką okupacją, a zatem prowadzenie jakichkolwiek poszukiwań i eksploatacji bez uprzedniej zgody ze strony władz Republiki Cypryjskiej stanowi naruszenie jej suwerenności.

Erol Kaymak wskazał również na powiązanie kwestii delimitacji cypryjskiej EEZ z grecko-tureckim sporem dotyczącym delimitacji szelfu kontynentalnego, zwłaszcza w basenie Morza Egejskiego, ale także w pobliżu południowych wybrzeży Turcji. Nie 
ulega wątpliwości, że uregulowanie spraw związanych z eksploatacją złóż gazu we wschodniej części Morza Śródziemnego będzie wymagało nie tylko porozumienia pomiędzy obiema cypryjskimi społecznościami, ale także normalizacji stosunków pomiędzy Turcją i Cyprem oraz uregulowania kwestii podziału szelfu kontynentalnego między Grecją a Turcją (Kaymak, 2012, s. 19-20).

\section{Kryzys finansowy na Cyprze a przyszle dochody z eksploatacji zlóż}

Wizja wielkich dochodów ze sprzedaży koncesji na wydobycie lub ze sprzedaży gazu nie mogła pojawić się w lepszym momencie. W marcu 2013 roku Republiką Cypryjską wstrząsnął najpoważniejszy kryzys finansowy w krótkiej historii tego państwa. Warto przypomnieć, że do tamtego momentu Cypr był prezentowany jako wzór gospodarki wolnorynkowej oraz miejsce przyjazne inwestorom. Sektor bankowy przynosił Greckim Cypryjczykom ogromne zyski i w dużej mierze pozwolił im na wyjście z bardzo trudnej sytuacji materialnej, w jakiej znaleźli się po 1974 roku. Przez lata społeczność międzynarodowa przymykała oko na nieproporcjonalnie duży rynek finansowy na Cyprze. Inwestorów nie zniechęcał nawet fakt, iż cypryjskie banki obracały przede wszystkim kapitałem spekulacyjnym. Wizja wysokich zysków przy stosunkowo niskim poziomie opłat i prowizji stanowiła wystarczająco silny argument na rzecz inwestowania na Cyprze.

Przy okazji należy wyraźnie podkreślić, że kryzys z 2013 roku uderzył przede wszystkim w gospodarkę Republiki Cypryjskiej. Nie wpłynął, przynajmniej bezpośrednio, na pogorszenie się sytuacji gospodarczej i finansowej Tureckich Cypryjczyków, którzy dysponują własną administracją, budżetem, niezależnym od południowego systemem bankowym oraz korzystają z tureckiego środka płatniczego - tureckiej liry.

Załamanie się cypryjskiego rynku finansowego oraz związany z nim kryzys budżetowy państwa były konsekwencjami światowego kryzysu finansowego, a zwłaszcza problemów greckich banków, z którymi mocno powiązane są główne banki cypryjskie. Choć pierwsze symptomy nieuchronności kryzysu pojawiły się już w połowie 2011 roku, prawdziwa zapaść nastąiła w dopiero w marcu 2013. Mechanizmy mające zabezpieczyć trzy główne banki (Laiki Bank, Bank of Cyprus, Hellenic Bank) okazały się być nieskuteczne. Zagrożone zostały nawet inwestycje obcokrajowców, którzy masowo korzystali z usług ponad 40 banków wyspecjalizowanych w obsłudze klientów spoza Cypru, choć jeszcze w 2012 roku analitycy twierdzili, że takiego zagrożenia nie było ${ }^{3}$.

W tym kontekście należy zwrócić uwagę na fakt, iż jeszcze przed wystapieniem kryzysu zakładano, że odkrycie złóż gazu ziemnego przełoży się na wzrost zamożności obywateli, a także przyczyni się do energetycznej niezależności Republiki Cypryjskiej. W momencie, gdy w marcu 2013 roku Cyprowi zabrakło w budżecie aż 10 mld euro,

3 Dowodem tego jest zachęta do inwestowania na Cyprze, opublikowana w prestiżowym „Country Review: Cyprus 2012". Analitycy przekonywali, że pomimo trudności, na jakie napotykały cypryjskie banki, ich działalność zagraniczna nie była zagrożona. Zob. Country Review: Cyprus 2012, s. 35 . 
udokumentowane złoża oraz koncesje na kolejne poszukiwania stały się cenną kartą przetargową, która miała uchronić Cypr przed koniecznością dużych cięć budżetowych i poddaniem się warunkom stawianym przez międzynarodowe instytucje finansowe. Władze Republiki Cypryjskiej sondowały nawet możliwość przyznania koncesji na poszukiwania i późniejszą eksploatację złóż przez firmy rosyjskie w zamian za przekazanie Cyprowi przez Federację Cypryjską wspominanych 10 mld USD lub wykup cypryjskich banków przez rosyjskie korporacje finansowe (Janik, 2013). W tej sprawie wypowiedział się nawet premier Federacji Rosyjskiej Dmitrij Miedwiediew: „Czekamy na ostateczne rozstrzygnięcia. Wówczas zdecydujemy czy jesteśmy zainteresowani bliższą współpracą z Cyprem. Kilka lat temu udzieliliśmy temu państwu pożyczki w wysokości 2,5 mld euro. Jeśli otrzymamy nowe propozycje, zastanowimy się nad dalszą pomoca. Póki co niczego nie ma na stole. Jeśli zaś chodzi o rezerwy gazu, to odpowiedź nie jest łatwa. Jesteśmy jednak gotowi wysłuchać wszystkich propozycji” (Kurasz, 2013).

Pytanie podstawowe brzmi jednak ile naprawdę warte są dotychczas odkryte cypryjskie złoża gazu? Według Michaela Emersona, przy zaniżonym szacunku i cenie około 200 dolarów za $1000 \mathrm{~m}^{3}$, cypryjskie złoża z sektora numer 12 są warte około 40 miliardów USD, czyli w przybliżeniu około 31 miliardów euro. Suma ta robi wrażenie, biorąc pod uwagę PKB Cypru na poziomie 18 miliardów euro i długu publicznym wynoszącym około 14 miliardów euro (Emerson, 2013, s. 167). To potencjalne dochody tylko z jednego sektora, które wystarczyłyby na ustabilizowanie sytuacji finansowej państwa. Jeżeli będzie ich więcej, Cypr może odczuć boom inwestycyjny i znaczący napływ gotówki, którą też będzie można zainwestować lub wykorzystać z korzyścią dla mieszkańców wyspy.

Warto jednak wyraźnie podkreślić, że w przypadku pola Afrodyty Cypr będzie musiał dzielić się przychodami z posiadającą koncesję na wydobycie amerykańską Noble Energy. Zgodnie z zawartą umową, Cypr ma otrzymywać 65\%, Noble Energy pozostałe $35 \%$. Biorąc pod uwagę także możliwości techniczne, Cypr zyskiwałby rocznie ze złóż Afrodyty około 2 miliardów euro (Emerson, 2013, s. 167).

\section{Wnioski}

Kwestie eksploatacji i delimitacji wyłącznych stref ekonomicznych we wschodniej części Morza Śródziemnego stanowią wielką szansę na pokojowe uregulowanie regionalnych sporów międzynarodowych, a zarazem wiążą się z dużym ryzykiem. Nierozwiązane spory polityczne, $w$ tym kwestia cypryjska, stoją na przeszkodzie tworzenia stabilnego systemu bezpieczeństwa oraz rozwoju wielostronnej współpracy. Niemniej, wraz z upływem lat powinna umacniać się świadomość istnienia wspólnego interesu oraz wzajemnych, wymiernych korzyści. W tym należy upatrywać szansy także na poprawę politycznej i gospodarczej sytuacji Cypru.

Bez wątpienia odkrycie bogatych złóż gazu ziemnego może stanowić również istotny impuls na rzecz wznowienia dialogu politycznego oraz wypracowania całościowego porozumienia na Cyprze. Jednakże analiza dotychczasowych działań podejmowanych przez reprezentantów obu społeczności potwierdza, iż wizja wymiernych korzyści 
płynących z eksploatacji złóż zamiast zbliżać, jeszcze bardziej dzieli Greckich i Tureckich Cypryjczyków. Owszem, władze Republiki Cypryjskiej zapewniają Tureckich Cypryjczyków o swej dobrej woli i chęci wzajemnie korzystnego podziału zysków pochodzących z eksploatacji podmorskich złóż gazu ziemnego. Problem jednak w tym, iż robią to forsując politykę faktów dokonanych, a zatem uzależniając przekazanie jakichkolwiek środków stronie Tureckich Cypryjczyków od uprzedniego uregulowania problemu cypryjskiego i utworzenia państwa federalnego.

Skala i możliwe konsekwencje kryzysu finansowego na Cyprze z wiosny 2013 roku stanowiły duże zaskoczenie zarówno dla społeczności międzynarodowej, jak i Greckich Cypryjczyków. Nie może zatem zaskakiwać fakt, iż władze Republiki Cypryjskiej postrzegają kwestię eksploatacji złóż przede wszystkim przez pryzmat potencjalnych, bardzo wysokich przychodów, które stworzyłyby realną szansę szybszego wyjścia z kryzysu finansowego, a także zmieniłyby rynek pracy oraz umożliwiłyby prowadzenie odważnej polityki inwestycyjnej z wykorzystaniem własnego kapitału.

Kwestie prawa do eksploatacji oraz czerpania korzyści ze sprzedaży gazu stanowią kolejny obszar cypryjskiego sporu. Przedstawiciele obu stron poświęcają dużo uwagi nie temu, by szukać wzajemnie korzystnych rozwiązań, lecz by w możliwie najbardziej efektywny sposób przeszkodzić drugiej stronie. Tym samym po raz kolejny dały o sobie znać największe problemy mieszkańców Cypru - wzajemny deficyt zaufania oraz brak dobrej woli ze strony kluczowych polityków. Pomimo rozmaitych deklaracji o woli współpracy, nietrudno odnieść wrażenie, że nie mają one niczego wspólnego z rzeczywistością i faktycznie podejmowanymi działaniami. Strony deklarują chęć współpracy, a jednocześnie prowadzą oddzielne poszukiwania i przeprowadzają kolejne próbne odwierty. Ponadto, podczas kryzysu finansowego na Cyprze wiosną 2013 roku, strona Greckich Cypryjczyków rozważała nawet możliwość sprzedaży koncesji na eksploatację kontrolowanych przez siebie złóż i to bez jakichkolwiek konsultacji ze stroną Tureckich Cypryjczyków.

\section{Bibliografia}

Adamczyk A. (2002), Cypr - dzieje polityczne, Wydawnictwo Akademickie Dialog, Warszawa.

Aphrodite's Gift: Can Cypriot Gas Power a New Dialogue? (2012), Crisis Group Europe Report №216, 2 April 2012.

Country Review: Cyprus 2012 (2012).

Eastern Mediterranean natural gas exploration focused on the Levant Basin, U.S. Energy Information Administration, http://www.eia.gov/todayinenergy/detail.cfm?id=12611.

Emerson M. (2013), Fishing for Gas and More in Cypriot Waters, „Insight Turkey”, nr 1.

Gürel A., Mullen F., Tzimitras H. (2013), The Cyprus Hydrocarbons Issue: Context, Positions and Future Scenarios, PCC Report 1/2013, PRIO Cyprus Centre, Nicosia.

Interview with Demetris Christofias (2012), „Turkish Policy Quarterly”, vol. 11, nr 1.

Interview with Nicos Anastasiades (2013), „Cyprus the Road Ahead”, July.

Janik M. (2013), Szatański plan dla raju podatkowego, „Bloomberg Businessweek Polska”, 25 marca-1 kwietnia 2013. 
Kariotos T.C. (2011), Hydrocarbons and the Law of the Sea in the Eastern Mediterranean: Implications for Cyprus, Greece, and Turkey, „Mediterranean Quarterly”, vol. 22, nr 2.

Kaymak E. (2012), Wealth Sharing and Geopolitical Strategies: Excluding Hydrocarbons from the Cyprus Negotiations, w: Cyprus Offshore Hydrocarbons: Regional Politics and Wealth Distribution, pod red. H. Faustmanna, A. Gürel, G. M. Reicheberga, PCC Report 1/2012, PRIO Cyprus Centre.

Konwencja Narodów Zjednoczonych o prawie morza, sporządzona w Montego Bay dnia 10 grudnia 1982 r., Dz. U. 2002.59.543.

Kurasz J. (2013), Dmitrij Miedwiediew: Mam nadzieję, że Cypr nie spowoduje załamania naszych relacji z Uniq, „Bloomberg Businessweek Polska”, 25 marca-1 kwietnia 2013.

Kyriakou M. X. (1989), Kryzys egejski, MAW, Warszawa.

Osiewicz P. (2008), Pokojowa regulacja kwestii cypryjskiej. Aspekty prawne i polityczne, Wydawnictwo Mado, Toruń.

Osiewicz P. (2013), Konflikt cypryjski, Wydawnictwo Naukowe PWN, Warszawa.

Spory - konflikty zbrojne - terroryzm. Dysfunkcjonalne czynniki wspótczesnych stosunków międzynarodowych (2006), pod red. W. Malendowskiego, Wydawnictwo Naukowe WNPiD UAM, Poznań.

Stocker J. (2012), No EEZ Solution: The Politics of Oil and Gas in the Eastern Mediterranean, „Middle East Journal”, vol. 66, nr 4.

The 1960 Treaties on Cyprus and Selected Subsequent Acts (2003), red. N. D. Macris, Bibliopolis, Mannheim-Möhnsee.

Turkey approves gas exploration in Cypriot waters (2012), http://www.reuters.com/article/2012/ 04/30/turkey-cyprus-oil-idUSL5E8FUEJL20120430.

Turkey launches oil and gas drilling in Northern Cyprus (2013), „Hürriyet Daily News” z 27.04.2013.

\section{Streszczenie}

Odkrycie wielkich złóż gazu ziemnego we wschodniej części Morza Śródziemnego stanowi szansę nie tylko na powszechne wzbogacenie, wzrost wolumenu inwestycji czy zwiększenie liczby miejsc pracy, ale może przyczynić się także do wzrostu regionalnego bezpieczeństwa i stanowić zachętę do uregulowania dotychczasowych sporów. Jest też druga strona medalu. Kwestia eksploatacji złóż może wywoływać nowe spory lub nawet doprowadzić do konfliktu. W przypadku złóż cypryjskich oba scenariusze są nadal prawdopodobne. Nieuregulowany problem polityczny wpływa bowiem pośrednio na kwestie energetyczne, zwłaszcza możliwości inwestycyjne związane z późniejszym przesyłem. Kluczową rolę odgrywają trzy strony: 1) Republika Cypryjska, która de facto jest państwem podzielonym i administrowanym jedynie przez Greckich Cypryjczyków; 2) nieuznawana przez społeczność międzynarodową, za wyjątkiem Turcji, Turecka Republika Północnego Cypru - państwo Tureckich Cypryjczyków oraz 3) Turcja. Celem niniejszego rozdziału jest zbadanie wpływu kwestii energetycznych na pozycję Cypru w regionie, jego sytuację gospodarczą oraz negocjacje pomiędzy Greckimi i Tureckimi Cypryjczykami.

Słowa kluczowe: Cypr, gaz ziemny, LNG, Turcja, wydobycie 
Natural gas fields in the Eastern Mediterranean: the implications for Cyprus

\section{Summary}

The discovery of large gas fields in the Eastern Mediterranean has resulted in new opportunities in the region, i.e. an increase in investment, in trade turnover as well as in the number of jobs. As far as the political aspects are concerned, such wealth and development potential can encourage politicians to seek peaceful resolutions to international disputes. Yet new resources can also mean new problems, for example, if states begin to compete for them, or for a fair share of income. In the case of Cyprus, both scenarios seem probable. The unsettled dispute affects energy issues, for example, blocking some proposed solutions with regard to gas transit. We can observe three main parties in the dispute, namely (1) the Republic of Cyprus, (2) the Turkish Republic of Northern Cyprus and (3) Turkey. The main aim of the paper is to analyse the influence of energy issues on the position of Cyprus in the region, as well as the Cypriot economic situation and the ongoing negotiation process between both Cypriot communities.

Key words: Cyprus, natural gas, LNG, Turkey, output 